This is the version of the article accepted for publication in European Law Journal published by Wiley: https://onlinelibrary.wiley.com/journal/14680386

Accepted version downloaded from SOAS Research Online:

https://eprints.soas.ac.uk/25641

\title{
The redenomination risk of exiting the Eurozone: \\ An estimation based on the Greek case
}

Costas Lapavitsas

SOAS, University of London

\begin{abstract}
Changing a country's currency involves a "redenomination risk" arising due to assets and liabilities impossible to redenominate because of contracts governed by foreign law. Depreciation or appreciation of the new currency could, therefore, result in losses or gains, thus creating a risk for economic agents. The risk can be estimated by splitting the economy into a Public, a Private, a Banking and a Central Banking sector, and summing up exposed aggregate assets and liabilities. This method is applied to Greece showing that exiting the EMU would certainly entail forbidding redenomination losses for the Greek Public sector, leading to default. Surprisingly, however, the impact on the Private and the Banking sectors would actually be positive (gain). The impact on the Bank of Greece would be ambiguous depending primarily on the legal status of TARGET2 liabilities. It is notable that even the Bank of Greece possesses a significant cushion in the form of bonds under foreign law. In all, the redenomination risk for the Greek economy is modest, with the exception of the Public sector.
\end{abstract}




\section{The persistent spectre of EMU exit ${ }^{1}$}

The prospect of currency redenomination emerged in the course of the Eurozone crisis and the most likely candidate was Greece. The country faced a major crisis as international private capital flows to the Greek state suddenly stopped in 2010. For several years public debt was serviced by receiving substantial loans from official lenders through three bail-out agreements, in 2010, 2011 and 2015. Macroeconomic policy was determined by the severe conditionality attached to these agreements, subject to periodic reviews by the IMF and the EU.

The terms of conditionality were effectively shaped by, first, the absence of substantial debt relief, including a debt write-off, and second, the impossibility of currency depreciation. Both factors resulted directly from the country's decision to avoid reintroducing its national currency, and thus to remain in the European Monetary Union. The main aim of conditionality was to achieve stability by eliminating the fiscal deficit as well as the deficit on current account. A further aim was to accelerate growth through wage reductions, market deregulation and privatisation.

Greece has engaged in severe fiscal contraction since 2010, with front-loaded cuts in public spending followed by major increases in taxes. During this period monetary and credit conditions also became tight as deposits drained away from Greek banks; moreover, banks faced heavy pressures to recapitalise and to deal with rising volumes of non-performing equity. Finally, income policy was severely restrictive and real wages could reasonably be said to have declined by a third since 2010 . The combined result was an unprecedented recession

\footnotetext{
${ }^{1}$ Thanks are due to S. Villemot, T. Mariolis, S. Cutillas, and J. Ebbing for comments on the text. All errors are the author's responsibility.
} 
cumulatively reducing GDP by a quarter during 2008-2013, while pushing unemployment above $27 \%$ in 2014 . $^{2}$

The recession brought a form of stability to the economy since about 2013-14. Severe fiscal austerity gradually eliminated the huge budget deficit recorded in 2010 , and after 2016 the country began to show substantial primary surpluses. The equally huge current account deficit recorded in 2008 was also greatly reduced. Achieving balance in the current account was due to the collapse of the domestic economy, which brought a precipitous decline in imports, while exports rose very modestly. In sum, stability was gained at the cost of national poverty that was heavily borne by wage labour and other low-income social strata. There has been no "balanced recovery" in Greece but only a dramatic shrinkage of the economy that greatly exacerbated inequality.

Growth has been very weak since 2014, and there is no realistic prospect of rapid acceleration making the losses from the recession and reducing the enormous unemployment. Especially notable in this respect is the collapse and lack of dynamism of investemtn. To make matters worse, the conditionality attached to the third bail-out agreed by Greece in August 2015 has forced the country to accept further extraordinary fiscal tightness by achieving primary surpluses rising to $3.5 \%$ of GDP in 2018 and for several years subsequently.

On balance, the Greek bail-out programmes were failures. They have certainly reduced the country's fiscal and external deficits but through tremendous contraction of GDP, with attendant social risks, and without creating conditions of rapid growth. Greece was made poorer and left in stagnation. Consequently, the question of an alternative strategy has never left the policy agenda. Such a

\footnotetext{
2 The literature on the Eurozone and the Greek crisis is extensive and much of it is not directly relevant to our purposes. For the theoretical and empirical analysis that supports this paper, see Lapavitsas, Mariolis, and Gavrielidis (2017); for a useful empirical summary of the crisis along more mainstream, lines, see Gourinchas, Philippon and Vayanos (2016); for additional penetrating observations on the macroeconomic policies applied to Greece, see also Nikiforos, Papadimitriou and Zezza (2016).
} 
strategy would inevitably include a deep restructuring of public debt and a boost to aggregate demand to reduce unemployment that would require, at the very least, lifting fiscal restrictions. The country would also need targeted industrial policy to strengthen the supply side by focusing mainly on its primary and secondary sectors. ${ }^{3}$ It is immediately apparent that none of these actions would be possible without Greece exiting the EMU and reintroducing its national currency.

In this respect Greece is only the most extreme case within the EMU. The option of exit also emerged at the margins of policy debate for other peripheral countries hit severely by the crisis (Portugal, Ireland, and Spain). After 2011 peripheral countries were stabilised through policies similar, but not nearly as severe, to Greece, and thus the issue of reintroducing national currencies became less pressing. Moreover, after years of poor economic performance, the Eurozone as a whole registered better growth results in 2017 . However, its fundamental institutional and economic weaknesses have hardly been addressed in the course of the crisis, especially the extraordinary current account surplus of Germany and the persistent application of fiscal austerity across the monetary union.

Consequently, the question of exit with its attendant risks and benefits has continued to receive attention, including in core countries. The recovery of monetary sovereignty has become a major political cleavage, the relevance of which is closely related to the eventual costs and benefits of exiting the euro. This is perhaps why it has become a central part of the political debate in both France and Italy in the last two years. The French presidential election in 2017 focused closely on the issue of the euro. Even more strongly, the Italian parliamentary elections in 2018 brought into prominence two political parties which jointly attracted more than half of the votes and were at the very least open to considering exit.

\footnotetext{
${ }^{3}$ See, Lapavitsas, Mariolis and Gavrielidis (2017).
} 
The longer-term viability of the common currency remains highly uncertain. It is, thus, necessary to consider the likely repercussions of reintroducing national currencies, in both peripheral and core countries. Of particular concern are the implications of redenomination followed by currency depreciation or appreciation. In the case of Greece it is apparent that a new currency would depreciate, although for other countries, such as Germany, it might be expected to appreciate. For analytical purposes, the effects of exchange rate changes could be usefully split between those on flows and those on stocks. For Greece, the effect on flows would fall within the classic ambit of currency depreciation analysis, including primarily its impact on exports and imports. The effect on stocks, on the other hand, is far less clear and forms the specific concern of this paper.

The stocks in question are basically monetary sums held or owed by various agents in the economy. After switching currency some monetary sums would be redenominated but some would remain denominated in the old currency because the governing law of their contracts would not allow for currency conversion, for instance, bank deposits held by residents with foreign banks. Therefore, the ensuing depreciation or appreciation of the new currency would affect the wealth of economic agents. The overall impact can also be thought of as a "balance sheet effect" which would change the value of the unconverted assets and liabilities of economic agents, resulting in either gain or loss of net wealth. If wealth changed as a result of redenomination, economic decisions could be affected, including consumption and investment. In case of substantial losses, for instance, there could be major falls in both consumption and investment. That would be a specific "redenomination risk" of exit.

Estimating the "balance sheet effect" of redenomination is a crucial part of preparing for EMU exit. By focusing on Greece it is possible to undertake a reasonably detailed investigation since the Greek economy has a less complex structure than others in the Eurozone, and the nature of the monetary sums 
held or owed by the fundamental agents is easier to ascertain. However, the method followed and the conclusions drawn would facilitate analysis for other countries.

In this light, section 2 considers the analytical problems posed by the "balance sheet effect" of exiting the EMU; section 3 turns to estimating the redenomination risk in general; section 4 estimates the redenomination risk for Greece by splitting the economy into four sectors, namely Public, Private (NonFinancial), Financial and the Central Bank; section 5 considers in further detail the redenomination problems for the Greek central bank especially in view of its TARGET2 exposure, and concludes.

\section{The "balance sheet effect" of exiting the EMU}

The basic steps of exiting the EMU and reintroducing a new currency are generally understood and need not detain us here, but clearly involve both economic and legal issues. ${ }^{4}$ The trigger of exit would probably be an Act of the Greek Parliament reasserting monetary sovereignty and redefining the unit of account under the Lex Monetae. The legal tender of the country would become the New Drachma, replacing the euro. The legal repercussions of this action and their implications for sovereignty in general, including Greek membership of the EMU and the European Union, would be many and complex. ${ }^{5}$

However, these complexities need not prevent us from estimating the redenomination risk. Suffice it to assume that the Greek state would declare an obligatory rate of conversion of the new for the old legal tender, which would apply to contracts closely connected with the state. In summary terms such contracts could be thought of as governed by Greek law. Two further issues

\footnotetext{
${ }^{4}$ See, for instance, Flassbeck and Lapavitsas (2015).

${ }^{5}$ See Petch and Meloni (2012, ch.4).
} 
would then emerge: first, determining the obligatory rate of conversion; second, ascertaining the contracts that would fall under Greek law.

Regarding the first, it would be easiest in administrative terms to institute a rate of conversion of $1: 1$ EUR/GRD, although it is certainly possible to adopt differential rates aiming for income and wealth redistribution. The conversion rate, for instance, could be 1.2:1 EUR/GRD for sums belonging to high-income groups and 0.8:1 EUR/GRD for low-income groups. However, the inevitable political frictions and the administrative difficulties that would result from such a policy cannot be ignored. Even more critical for our purposes is that differential rates of conversion would not affect at all the redenomination risk. Therefore, for the purposes of this paper, suffice it to assume that the conversion rate would be 1:1.

Regarding the second, it should be mentioned at the outset that the relevant legal field is large and variable. ${ }^{6}$ The euro is the legal tender of Eurozone member states, having replaced their national currencies. If a member state exited the Eurozone and adopted a new currency, there would be two possible outcomes with regard to existing euro-denominated contracts: either payment obligations would continue to be payable in euro (under the Lex Monetae of the Eurozone member states); or payment obligations would be redenominated in the new currency (under the Lex Monetae of the departing member). Unfortunately the grey area between the two would be substantial, and thus persistent litigation could be expected for a long time after the currency switch. 7 It could be assumed, for instance, that the bulk of wage and salary contracts would fall under Greek law, and hence the conversion would be at 1:1. However, financial assets would generally be under both Greek and foreign

\footnotetext{
${ }^{6}$ See Proctor (2010); see also Petch and Meloni (2012, ch. 4 and 5). In Greece there has been very little written by lawyers on the issue of exit, with the notable exception of Miliarakis; see, for instance, (2015) and (2016).

${ }^{7}$ In this respect see the path-breaking work by Nordwig and Firoozye (2012), further elaborated by Nordwig (2014). The approach to redenomination risk in this paper draws on that work. There is considerable scope for specialist legal work on this issue.
} 
law, as would be financial liabilities. Therefore, a proportion of both assets and liabilities would be impossible to convert and would remain in euro. That is precisely the source of the redenomination risk, as was mentioned in the previous section.

Strictly speaking, the redenomination risk would arise because after the introduction of the New Drachma the currency would probably be devalued in the foreign exchange markets. The rate of exchange relatively to the euro would be likely to follow a so-called J-curve path, i.e., it would rapidly decline during the initial period but gradually recover toward a more stable position. The degree of depreciation would not be easy to predict, but note that the Greek current account has been broadly in balance since 2015, mostly due to the collapse of imports in the course of the recession, thus limiting the potential depreciation pressures. However, the degree of depreciation is irrelevant to estimating the sources of the redenomination risk although, obviously, the deeper the depreciation, the greater will be the resulting change in wealth.

The redenomination risk is important because it contributes to the overall effect of currency depreciation on the Greek economy. To be more specific, depreciation can be expected to have a positive impact on the flows of the Greek economy in the short to medium term, reducing imports, increasing exports and giving a boost to aggregate demand and income. ${ }^{8}$ In the long term the impact of depreciation would be fully absorbed by the price level, but during the intervening period the Greek productive sector would have an opportunity to restructure itself and capture markets domestically and internationally, particularly if the country also implemented an industrial policy capable of boosting the manufacturing sector of Greece. This would be a strong benefit from the introduction of the new currency.

${ }^{8}$ See Katsinos and Mariolis (2012). 
However, the impact of depreciation on monetary and financial stocks, and the likely impact of those on economic activity, has not been considered in the course of the Greek crisis. In terms of the broader economic literature this impact could be considered as a type of "balance sheet effect" characteristic of "third generation currency crisis models". Following the Asian crisis of 1997-8, Krugman (1999 and 2000) argued that a depreciation could be contractionary if firm revenues were denominated in domestic currency while debts were dollar-denominated. A depreciation would then lead to deterioration of balance sheets, thus negatively affecting borrowing and investment. The "balance sheet effect" has also been discussed in the extensive literature on the causes of financial crises, which is not directly relevant to this paper. ${ }^{9}$

In this light, depreciation in Greece following the change of currency and the redenomination of financial assets would raise the domestic currency value of both the assets and the liabilities that would remain denominated in euros. The overall "balance sheet effect" might be either positive or negative depending on the balance of the unconverted assets and liabilities. Generally speaking, if firms or other sectors faced losses, that could potentially affect investment and consumption decisions, perhaps even negating the positive direct flow effects of depreciation. It is conceivable that the "balance sheet effect" might even be enough to generate a recession. This is precisely why it is vital to estimate the redenomination risk following exit from the EMU. 10

\section{Estimating the redenomination risk}

The basic method for estimating the redenomination risk of exit has been proposed by Nordvig and Firoozye (2012) and Nordvig (2014). For our

\footnotetext{
${ }^{9}$ Note that there are inherent affinities between the "balance sheet" approach and the approach to crisis that draws on Minsky, which are clear in the case of Arestis and Glickman (2002).

${ }^{10}$ Very different outcomes would obtain for a country that faced appreciation of its currency after exit, as in the case of Germany. The method of estimation in this paper also applies to Germany.
} 
purposes, it has been further developed by Durand and Villemot (2016). ${ }^{11}$ Moreover, important methodological insights can be obtained from Minenna, et.al., (2017), particularly with reference to Italian public debt.

The advance made in this paper is to add greater depth and policy detail to the estimates by splitting the Greek economy into four sectors and examining the aggregated financial accounts of each sector line by line using mostly national data. The aim is to identify and sum up the entries that are not expected to fall under Greek law, thus remaining in euro, on both the liability and the asset side. The difference of Assets minus Liabilities define what is called the Net Relevant Position, which is a measure of the net wealth at risk in case of redenomination. If the new currency depreciated, there would be losses on unconverted liabilities, but gains on unconverted assets. The risk of redenomination, therefore, would depend on the size of the Net Relevant Position for each sector.

Table 1 summarises the method:

Table 1.

Redenomination risk

\begin{tabular}{|l|l|}
\hline Assets & Liabilities \\
\hline Under Lex Monetae & Under Lex Monetae \\
\hline Remaining in euro A & Remaining in euro $\quad$ L \\
\hline
\end{tabular}

Thus:

Net Relevant Position: A - L

\footnotetext{
${ }^{11}$ The study by Amiel and Hyppolite (2015) also uses fundamentally the same method but looks only at firm-level data and, crucially, ignores the asset side.
} 
To estimate the redenomination risk for the Greek economy it helps to split the economy into four sectors that would bear the greatest impact from the change of currency, namely, the Public Sector, the Private (non-Bank) Sector, the Banking Sector and the Bank of Greece. ${ }^{12}$ The financial account of each sector could then be examined to establish the Net Relevant Position. Finally, by considering all sectors together, an assessment could be reached for the redenomination risk of the economy as a whole.

Before engaging with the financial account of each sector, however, it is important to obtain a picture of the international exposure of Greece by examining its International Investment Position (IIP), which is the value of foreign assets owned by Greek residents compared to the value of Greek assets owned by non-residents. The Net IIP provides a first approximation of the exposure of Greece abroad, and hence of the likely impact of redenomination. Further general evidence is also adduced by considering Bank of International Settlements and World Bank data on Greek external indebtedness. The sectorial financial accounts are examined in section 4 to ascertain the Net Relevant Positions.

Last but not least, estimating the redenomination risk is similar to hitting a moving target, since the balance sheet entries of all sectors change on a constant basis. The estimation in this paper has been performed for Greece for the third quarter of 2016. The results broadly hold for the subsequent period, allowing for strong conclusions. Moreover, the method of estimation remains applicable to other countries.

\section{International assets and liabilities of the Greek economy}

\footnotetext{
${ }^{12}$ Strictly speaking the BoG is not a sector of the economy but the size of its balance sheet and its importance in the process of exit justify including as a separate sector for our purposes.
} 


\subsection{Net International Investment Position}

Table 2 gives a simplified picture of the International Investment Position of Greece in the third quarter of 2016:

Table 2. Greek International Investment Position, Q3 2016, EURmn

\begin{tabular}{|l|l|l|}
\hline & Assets & Liabilities \\
\hline Direct Investment & 27519 & 26890 \\
\hline Portfolio Investment & 122573 & 44211 \\
\hline Financial Derivatives & 1228 & 9265 \\
\hline Other Investment & 80202 & 391636 \\
\hline Reserve Assets & 6833 & \\
\hline Total & 238355 & 472003 \\
\hline Net IIP & -233648 & \\
\cline { 1 - 2 } & &
\end{tabular}

Source: Constructed from BoG, International Investment Position, Quarterly Data, available at:

http://www.bankofgreece.gr/Pages/en/Statistics/externalsector/international.aspx

The Net IIP of Greece, as should be expected for a country that is heavily indebted to the rest of the world, is strongly negative. Among the components of IIP, the category of Direct Investment is typically governed by the national law of the country in which the direct investment takes place, and hence leaves practically no scope for redenomination. ${ }^{13}$ The category of Financial Derivatives is, to all intents and purposes, governed by non-Greek law and it would thus also be impervious to redenomination. ${ }^{14}$ Fortunately for Greece, financial derivatives are a minor component of the country's exposure, which will also be considered briefly below. Finally, the category of Reserve Assets

\footnotetext{
${ }^{13}$ See Nordvig and Firoozye (2012) and Nordvig (2014).

${ }^{14}$ See Nordvig and Firoozye (2012), Nordvig (2014) and also Minenna, et.al. (2017).
} 
would remain denominated in euro providing a first port of call for the required foreign exchange reserves after redenomination.

The components of IIP that are numerically dominant and matter for our purposes are Portfolio Investment and Other Investment. The former comprises essentially equity and bond investments; the latter comprises loans by banks or, more significantly in the case of Greece, official lenders; Tables 3, 4 and 5 sum up both in terms of the four sectors.

Consider first Portfolio Investment:

Table 3. Portfolio Investment, IIP, Greece, Q3 2016, EURmn

\begin{tabular}{|l|l|l|l|l|l|l|l|l|l|l|}
\hline & EQUITY & & & & & DEBT & & & & \\
\hline & Securities & & $\begin{array}{l}\text { Investment } \\
\text { Funds }\end{array}$ & & & $\begin{array}{l}\text { Short- } \\
\text { term }\end{array}$ & & $\begin{array}{l}\text { Long- } \\
\text { term }\end{array}$ & & \\
\hline & Assets & Liab. & Assets & Liab. & & Assets & Liab. & Assets & Liab. & \\
\hline & & & & & Net & & & & & Net \\
\hline Public & 17 & 0 & 3 & 0 & 20 & 0 & 1161 & 22 & 28205 & -29344 \\
\hline Private & 185 & 6892 & 8022 & 0 & 1315 & 12 & 0 & 2467 & 2158 & 321 \\
\hline Banking & 153 & 3964 & 62 & 0 & -3749 & 32 & 0 & 54778 & 1144 & 53666 \\
\hline BoG & 0 & 0 & 0 & 0 & 0 & 530 & 0 & 45575 & 0 & 46105 \\
\hline Total & 355 & 10856 & 8087 & 0 & -2414 & 574 & 1161 & 102842 & 31507 & 70748 \\
\hline Net Portfolio Investment & 68334 & & & & & & & & &
\end{tabular}

Source: Constructed from BoG, International Investment Position, Quarterly Data, available at:

http://www.bankofgreece.gr/Pages/en/Statistics/externalsector/international.aspx

Several important points are immediately apparent from Table 3. First, the net position of the country is strongly positive; all sectors are also positive, except for the Public Sector, probably due to short term Greek bonds held by the European Central Bank but also by the private sector. Second, the Private Sector holds and has issued insignificant volumes of bonds with regard to IIP. Third, both the Banking Sector and the BoG have positive positions. The bond 
holdings of Greek banks are clearly related to the debt restructuring of 201112, the Private Sector Involvement, as part of which some Greek state bonds were swapped for foreign bonds. The most remarkable aspect of Table 3, however, are the substantial foreign bond holdings of the BoG, an aspect of Greek redenomination that will be examined in further detail in subsequent sections.

Consider now Other Investment:

Table 4. Other Investment, IIP, Greece, Q3 2016, EURmn

\begin{tabular}{|l|l|l|l|}
\hline & Assets & Liabilities & \\
\hline & & & Net \\
\hline Public & 2299 & 236856 & -234557 \\
\hline Private & 52720 & 15718 & 37002 \\
\hline Banking & 23099 & 46438 & -23339 \\
\hline BoG & 2077 & 92624 & -90547 \\
\hline Total & 80195 & 391636 & -311441 \\
\hline
\end{tabular}

Source: Constructed from BoG, International Investment Position, Quarterly Data, available at:

http://www.bankofgreece.gr/Pages/en/Statistics/externalsector/international.aspx

Other Investment is clearly the main source of the negative overall position of the country: all sectors are negative, with the exception of the Private Sector. Fundamental to it is the overwhelmingly negative position of the Greek Public Sector, driven by the bail-out loans obtained since 2010. The position of the remaining sectors, however, calls for closer examination in Table 5:

Table 5.

Currency and Deposits, IIP, Greece, Q3 2016, EURmn 


\begin{tabular}{|l|l|l|l|}
\hline & Assets & Liabilities & \\
\hline & & & Net \\
\hline Public & 0 & 0 & 0 \\
\hline Private & 52206 & 0 & 52206 \\
\hline Banking & 18740 & 46438 & -27698 \\
\hline BoG & 1357 & 92624 & -91267 \\
\hline Total & 72303 & 139062 & -66759 \\
\hline
\end{tabular}

Source: Constructed from BoG, International Investment Position, Quarterly Data, available at:

http://www.bankofgreece.gr/Pages/en/Statistics/externalsector/international.aspx

The negative position of the Banking Sector is largely due to the monetary liabilities that Greek banks have to other country banks as well as to their securitisation liabilities, as will be seen in detail in subsequent sections. The positive position of the Private Sector is due largely to its holdings of euro banknotes and other deposits abroad. The negative position of the BoG is due to the issuing of euro banknotes and, much more significantly, to borrowing from the Eurosystem to provide liquidity to Greek banks (mostly TARGET2, i.e. liabilities within the Trans-European Automated Real-time Gross Settlement Express Transfer System). These entries present the most complex problems of redenomination, and will be discussed in sections 4 and 5 .

In sum, the IIP data provides a useful overall and sectorial picture of the position of Greece, indicating that the country is heavily indebted abroad but mostly through the public sector. The position of the BoG is also strongly negative but requires closer investigation. The position of the other two sectors also requires more detailed consideration. To this purpose the IIP data is of limited use because, first, it lacks sufficient detail and, second, the ownership of assets by residents and non-residents does not necessarily correspond to the governing law of the specific contracts. A Greek asset owned by a non-resident, for instance, could still be governed by Greek law. To ascertain the Net Relevant Position of the sectors and of the economy as a whole, therefore, it is necessary to consider far more granular data. 
Before considering detailed evidence from sectorial balance sheets, however, it is helpful to sum up general data from the Bank of International Settlements as well as from the World Bank.

\subsection{BIS and World Bank Data}

Table 6 provides a picture of securities outstanding abroad:

Table 6. Stock of international debt securities outstanding, Greece, Q3 2016, \$bn

\begin{tabular}{|l|l|l|}
\hline Resident issuers & Debt & \\
\hline & & $\begin{array}{l}\text { Of which up to and } \\
\text { including one year }\end{array}$ \\
\hline Banks & 29 & 12.5 \\
\hline Non-bank financial & 6.7 & 0.6 \\
\hline Non-financial & 3.2 & 1 \\
\hline Government & 24.9 & 14.1 \\
\hline Total & 63.8 & 25.2 \\
\hline
\end{tabular}

Source: Constructed from BIS Debt Securities Statistics, available at:

\section{http://www.bis.org/statistics/c3-GR.pdf}

According to the BIS, the foreign securities exposure of Greece is almost entirely denominated in euro. The difficulty of arriving at reliable figures for our purposes becomes immediately apparent when comparing Table 6 to Tables 3 and 4. What is important from Table 6, however, is, first, confirmation of the remaining securities exposure of the Greek government, which most probably amounts to the holdings of the European Central Bank (ECB) and, second, the very limited securities exposure of the Greek Private Sector. 
Table 7 provides a picture of the total, or 'gross', external debt position of Greece:

Table 7 Gross external debt position, Greece, Q3 2016, \$mn, securities at market value

\begin{tabular}{|l|l|l|}
\hline Total debt & & 483047 \\
\hline Among which & & \\
\hline By sector & Government & 297130 \\
\hline & BoG & 103378 \\
\hline By instrument & & \\
\hline & SDR & 1092 \\
\hline & Currency and Deposits & 154507 \\
\hline & Debt Securities & 36461 \\
\hline & Loans & 280583 \\
\hline & Trade Credit & 798 \\
\hline & Other Debt & 125 \\
\hline & Direct Investment & 9481 \\
\hline
\end{tabular}

Source: Constructed from World Bank, Quarterly External Debt Statistics, available at:

http://databank.worldbank.org/data/views/reports/ReportWidgetCustom.aspx?Report Name= Table-1-SDDS-new\&ld=4f2f0c86

Once again it is apparent that the publicly available data from international organisations requires considerable care before being used for our purposes. Still, Table 7 confirms the broad parameters of Greek external debt, including the low exposure of the Greek Private Sector, also in terms of trade credit. It is, nonetheless, apparent that for a deep analysis of redenomination risk it would be necessary to consider sectorial data, including aggregated balance sheets. This is undertaken in the following section. 


\section{Sectorial Financial Accounts and Net Relevant Positions}

\section{$4.1 \quad$ Public Sector}

Consider first the position of the Greek Public Sector which, as is clear from the discussion in section 3 , has by far the largest exposure abroad driven by the public debt. The composition of the Greek public debt is a follows:

Table 8. Composition of Budgetary Central Government Debt, Greece, 31 Dec 2016, EUR mn

\begin{tabular}{|l|l|l|l|}
\hline $\begin{array}{l}\text { Bonds and Short- } \\
\text { term notes }\end{array}$ & $\begin{array}{l}\text { Bonds issued } \\
\text { domestically }\end{array}$ & 54354.01 & 7607.15 \\
\hline & $\begin{array}{l}\text { Bonds issued } \\
\text { abroad }\end{array}$ & 2277.07 & \\
\hline & $\begin{array}{l}\text { Securitisation } \\
\text { issued abroad }\end{array}$ & 86.51 & \\
\hline & $\begin{array}{l}\text { Short-term } \\
\text { notes }\end{array}$ & 14889.56 & 254750.99 \\
\hline Loans & BoG & 3321.28 & \\
\hline & $\begin{array}{l}\text { Other domestic } \\
\text { Special purpose } \\
\text { and bilateral }\end{array}$ & 747.63 & \\
\hline & 749.79 & \\
\hline
\end{tabular}




\begin{tabular}{|l|l|l|l|}
\hline & $\begin{array}{l}\text { Financial } \\
\text { Support } \\
\text { Mechanism }\end{array}$ & 227660.49 & \\
\hline & Repos & 11362.75 & \\
\hline Total & & & 326358.14 \\
\hline Source: Constructed from Greek Public Debt Management Agency:
\end{tabular}

http://www.pdma.gr/attachments/article/37/Bulletin\%20No 84.pdf

According to the Greek Public Debt Management Agency, $97 \%$ of the debt is euro-denominated. ${ }^{15}$ By selecting the entries of Table 8 that would not be redenominated after a change of currency and by further mobilising the evidence from section 3, it is possible to construct the Net Relevant Position of the Greek Public Sector. Needless to say, assumptions have to be made and judgement exercised in this connection:

Table 9. Net Relevant Position of the Greek Public Sector, Dec 2016, EURmn

\begin{tabular}{|l|l|l|}
\hline ASSETS & \multicolumn{2}{l|}{ LIABILITIES } \\
\hline $\begin{array}{l}\text { Portfolio and } \\
\text { Other } \\
\text { Investments } \\
\text { (from Table 3 and } \\
4)\end{array}$ & From Loans \\
\hline & & \multicolumn{2}{|l|}{} \\
\hline & $\begin{array}{l}\text { Special purpose } \\
\text { and bilateral }\end{array}$ & 7479.79 \\
\hline & $\begin{array}{l}\text { Financial Support } \\
\text { Mechanism }\end{array}$ & 227660.49 \\
\hline & Other external & 4739.05 \\
\hline & Total Loans & 239879.33 \\
\hline
\end{tabular}

\footnotetext{
${ }^{15}$ Note that in December 2016 there were also roughly EUR13bn of Greek state guarantees to a variety of public enterprises and other recipients. These do not directly affect the redenomination risk and could be left out of account. See http://www.pdma.gr/attachments/article/37/Bulletin\%20No 84.pdf
} 


\begin{tabular}{|c|c|c|c|}
\hline & & From Bonds & \\
\hline & & $\begin{array}{l}\text { Bonds issued } \\
\text { domestically } \\
\text { minus bonds held } \\
\text { by the ECB, } \\
\text { estimated at } \\
28205 \text {, from } \\
\text { Table } 3\end{array}$ & 26149.01 \\
\hline & & $\begin{array}{ll}\text { Bonds issued } \\
\text { abroad }\end{array}$ & 2277.07 \\
\hline & & $\begin{array}{l}\text { Securitisation } \\
\text { issued abroad }\end{array}$ & 86.51 \\
\hline & & $\begin{array}{l}\text { Short-term notes } \\
\text { externally held, } \\
\text { from Table } 3\end{array}$ & 1161 \\
\hline & & Total Bonds & 29673.59 \\
\hline Total & 2241 & Total & 269552.92 \\
\hline Net $\mathrm{F}$ & ition & -267311.92 & \\
\hline
\end{tabular}

The strongly negative position of the Greek public sector is entirely due to the bail-out policies applied to Greece. The governing law of the vast bulk of Greek public debt in 2010 was actually Greek, but it was systematically switched to foreign law as bail-out funds were received. In effect, and as is borne out by Table 9, public debt was placed beyond the sovereign power of the Greek state, and it would prove impossible to redenominate in the event of exiting the EMU. This is a truly extraordinary abdication of power on the part of the Greek state in historical terms, which has dramatically worsened the implications of redenomination. Under current conditions, in the event of EMU exit the Greek government would be obliged immediately to declare default and issue a call for negotiations to achieve a substantial debt write-off. 


\subsection{Private (Non-Banking) Sector}

Given that there is no aggregated balance sheet of the Private (Non-Banking) Sector the only way to assess the relevant redenomination risk is by deploying the data from the Greek IIP in Tables 3, 4 and 5. Thus:

\section{Table 10. Net Relevant Position of the Greek Private (Non-Banking) Sector, Q3 2016, EURmn}

\begin{tabular}{|l|l|l|}
\hline ASSETS & \multicolumn{2}{|l|}{ LIABILITIES } \\
\hline $\begin{array}{l}\text { Portfolio and } 63406 \\
\text { Other Investment }\end{array}$ & $\begin{array}{l}\text { Portfolio and } \\
\text { Other Investment }\end{array}$ & $\mathbf{2 4 7 6 8}$ \\
\hline $\begin{array}{l}\text { Of which Currency and Deposits } \\
52206\end{array}$ & \\
\hline Net Relevant Position & $\mathbf{3 8 6 3 8}$ \\
\hline
\end{tabular}

The limited exposure of the Greek Private Sector to international financial markets together with the relatively large amount of Currency and Deposits held by the Private Sector imply that the Net Relevant Position is actually substantially positive. This is a large buffer that would protect the Private Sector from the shock of redenomination but its effectiveness would also depend on its distribution among households, enterprises and other institutions. The available information on that issue is not detailed enough to allow for an assessment, however.

\subsection{Banking Sector}


Analysis of the Net Relevant Position of the Greek Banking Sector should depart from the aggregated balance of Monetary Financial Institutions which provides a detailed breakdown of sector's exposed Assets and Liabilities. A simplified version of the balance sheet is given in Table 11:

Table 11. Simplified Aggregated Balance Sheet of Greek MFls, December 2016, EUR mn

\begin{tabular}{|c|c|c|c|c|c|c|c|}
\hline \multicolumn{4}{|l|}{ ASSETS } & \multicolumn{4}{|l|}{ LIABILITIES } \\
\hline Cash & & & 1754 & $\begin{array}{l}\text { Liabilities to } \\
\text { BoG }\end{array}$ & & & 66617 \\
\hline $\begin{array}{l}\text { Claims on } \\
\text { BoG }\end{array}$ & & & 907 & $\begin{array}{l}\text { Liabilities to } \\
\text { MFls }\end{array}$ & Of which & & 24416 \\
\hline \multirow{4}{*}{$\begin{array}{l}\text { Claims on } \\
\text { MFls }\end{array}$} & Of which & & 17488 & & Domestic & 535 & \\
\hline & Domestic & 648 & & & $\begin{array}{l}\text { Other } \\
\text { Euro } \\
\text { Area }\end{array}$ & 10157 & \\
\hline & $\begin{array}{l}\text { Other } \\
\text { Euro } \\
\text { Area }\end{array}$ & 3428 & & & $\begin{array}{l}\text { Other } \\
\text { Countries }\end{array}$ & 13606 & \\
\hline & $\begin{array}{l}\text { Other } \\
\text { Countries }\end{array}$ & 13412 & & & Other & 117 & \\
\hline \multirow[t]{4}{*}{$\begin{array}{l}\text { Claims on } \\
\text { non-MFls }\end{array}$} & Of which & & 206525 & $\begin{array}{l}\text { Deposits and } \\
\text { Repos of non- } \\
\text { MFls }\end{array}$ & Of which & & 157460 \\
\hline & Domestic & 202070 & & & Domestic & 132112 & \\
\hline & $\begin{array}{l}\text { Other } \\
\text { Euro } \\
\text { Area }\end{array}$ & 2139 & & & $\begin{array}{l}\text { Other } \\
\text { Euro Area }\end{array}$ & 1718 & \\
\hline & $\begin{array}{l}\text { Other } \\
\text { Countries }\end{array}$ & 2315 & & & $\begin{array}{l}\text { Other } \\
\text { Countries }\end{array}$ & 6384 & \\
\hline \multirow[t]{4}{*}{ Securities } & Of which & & 62865 & $\begin{array}{l}\text { Securitisation } \\
\text { Liabilities }\end{array}$ & & & 17246 \\
\hline & Domestic & 11749 & & $\begin{array}{l}\text { Money Market } \\
\text { Funds, Debt } \\
\text { Securities }\end{array}$ & & & 2982 \\
\hline & $\begin{array}{l}\text { Other } \\
\text { Euro } \\
\text { Area }\end{array}$ & 32764 & & $\begin{array}{l}\text { Capital and } \\
\text { Reserves }\end{array}$ & & & 78436 \\
\hline & $\begin{array}{l}\text { Other } \\
\text { Countries }\end{array}$ & 18352 & & $\begin{array}{l}\text { Financial } \\
\text { Derivatives }\end{array}$ & & & 4424 \\
\hline \multirow[t]{3}{*}{$\begin{array}{l}\text { Shares and } \\
\text { Other }\end{array}$} & Of which & & 9347 & $\begin{array}{l}\text { Remaining } \\
\text { Liabilities }\end{array}$ & & & 17486 \\
\hline & Domestic & 4246 & & & & & \\
\hline & $\begin{array}{l}\text { Other } \\
\text { Euro } \\
\text { Area }\end{array}$ & 2193 & & & & & \\
\hline
\end{tabular}




\begin{tabular}{|l|l|l|l|l|l|l|l|}
\hline & $\begin{array}{l}\text { Other } \\
\text { Countries }\end{array}$ & 2907 & & & & & \\
\hline $\begin{array}{l}\text { Financial } \\
\text { Derivatives }\end{array}$ & & & 3236 & & & & \\
\hline $\begin{array}{l}\text { Remaining } \\
\text { Assets }\end{array}$ & & & 49699 & & & & \\
\hline Total & & & 351821 & Total & & & 351821 \\
\hline
\end{tabular}

Source: Constructed from BoG, Aggregated Balance Sheet of MFls excluding the BoG, available at:

http://www.bankofgreece.gr/Pages/en/Statistics/monetary/nxi.aspx

It is clear from Table 11 that the links between the Greek banking system and the rest of the European banking system are weak. The great bulk of bank assets comprises domestic loans, although Greek banks also hold a substantial volume of non-domestic securities. Most of these were probably issued by official lending institutions (mostly European lenders) to replace Greek government bonds at the time of the Private Sector Involvement (PSI). The PSI was effectively a major "haircut" of Greek public bonds held mostly by domestic lenders, which took place in 2011-12. The Asset side, consequently presents few problems with regard to assessing the feasibility of redenomination. The only significant unknown are Remaining Assets, which are a large part of the balance sheet that cannot be categorised by definition.

As for liabilities, once again the great bulk of bank liabilities are to domestic agents, mostly private deposits and the BoG. The latter obviously relates to the huge provision of liquidity to Greek banks throughout the crisis (some of it in the form of Extraordinary Liquidity Assistance) on which more below in connection with the balance sheet of the BoG. From the perspective of redenomination bank liabilities present few problems, with the exception again of Remaining Liabilities, which are significant and, again, cannot be categorised.

Thus, the Relevant Position of the Greek Banking Sector would be: 
Table 12 Net Relevant Position of the Greek Banking Sector, December 2016, EUR mn

\begin{tabular}{|c|c|c|c|}
\hline \multicolumn{2}{|l|}{ ASSETS } & \multicolumn{2}{|l|}{ LIABILITIES } \\
\hline Cash & 1754 & $\begin{array}{l}\text { Liabilities to MFIs } \\
\text { other euro area }\end{array}$ & 10157 \\
\hline $\begin{array}{l}\text { Claims on MFIs } \\
\text { other euro area }\end{array}$ & 3428 & $\begin{array}{l}\text { Liabilities to MFIs } \\
\text { other countries }\end{array}$ & 13606 \\
\hline $\begin{array}{l}\text { Claims on MFIs } \\
\text { other countries }\end{array}$ & 13412 & $\begin{array}{l}\text { Securitisation } \\
\text { Liabilities }\end{array}$ & 17246 \\
\hline $\begin{array}{l}\text { Securities other euro } \\
\text { area }\end{array}$ & 32764 & Financial derivatives & 4424 \\
\hline $\begin{array}{l}\text { Securities other } \\
\text { countries }\end{array}$ & 18352 & & \\
\hline $\begin{array}{l}\text { Shares other euro } \\
\text { area }\end{array}$ & 2193 & & \\
\hline $\begin{array}{l}\text { Shares other } \\
\text { countries }\end{array}$ & 2907 & & \\
\hline Financial derivatives & 3236 & & \\
\hline Total & 78046 & Total & 45433 \\
\hline \multicolumn{2}{|c|}{ Net Relevant Position } & \multicolumn{2}{|l|}{32613} \\
\hline
\end{tabular}

The low exposure of the Greek Banking Sector to international markets and the relatively high holdings of bonds that cannot be redenominated entail a large positive Net Relevant Position. Whether the positive net position could function as a buffer in case of exit from the EMU, however, depends on the legal status of the bonds issued by European institutions at the time of the PSI. Note, finally, that although Greek banks have relative large assets and liabilities that cannot be classified, the Remaining Assets are nearly three times the Remaining Liabilities; it is likely that the Net Relevant Position would be positive in this respect too.

\subsection{Bank of Greece}

The most complex problems of redenomination are posed by the BoG which is not, of course, a proper sector of the economy but the pivot of the Greek credit and monetary system. The BoG is part of the Eurosystem and one of the 
owners of the ECB. It played a crucial role in the course of the Greek crisis by providing liquidity to Greek banks as the latter lost both deposits and access to international markets. The liquidity provided by the BoG has been ultimately supplied by the Eurosystem, to which the BoG has become heavily indebted. The basic mechanism was TARGET2, the performance of which has generated a large literature in recent years. ${ }^{16}$

Table 13 provides a simplified version of the balance sheet of the BoG to facilitate analysis:

Table 13. Simplified Balance Sheet of the Bank of Greece, December 2016, EUR mn

\begin{tabular}{|c|c|c|c|c|c|c|c|}
\hline \multicolumn{4}{|l|}{ ASSETS } & \multicolumn{4}{|l|}{ LIABILITIES } \\
\hline $\begin{array}{l}\text { Claims on } \\
\text { MFls }\end{array}$ & & & 68676 & $\begin{array}{l}\text { Banknotes and } \\
\text { coins }\end{array}$ & & & 30728 \\
\hline $\begin{array}{l}\text { Claims on } \\
\text { non-MFls }\end{array}$ & & & 7862 & $\begin{array}{ll}\text { Liabilities } & \text { to } \\
\text { MFIs } & \\
\end{array}$ & $\begin{array}{l}\text { Of } \\
\text { which }\end{array}$ & & 73164 \\
\hline Securities & Of which & & 58319 & & $\begin{array}{l}\text { To } \\
\text { Other } \\
\text { Euro } \\
\text { Area }\end{array}$ & 72257 & \\
\hline & Domestic & 5041 & & $\begin{array}{l}\text { Deposits and } \\
\text { repos of non- } \\
\text { MFls }\end{array}$ & & & 10374 \\
\hline & $\begin{array}{l}\text { Other } \\
\text { Euro } \\
\text { Area }\end{array}$ & 36784 & & $\begin{array}{l}\text { Capital and } \\
\text { reserves * }\end{array}$ & & & 10635 \\
\hline & $\begin{array}{l}\text { Other } \\
\text { Countries }\end{array}$ & 16494 & & $\begin{array}{l}\text { Remaining } \\
\text { Liabilities }\end{array}$ & & & 18107 \\
\hline Reserves & & & 4742 & & & & \\
\hline Other & & & 3409 & & & & \\
\hline Total & & & 143008 & Total & & & 143008 \\
\hline
\end{tabular}

Source: Constructed from BoG, Balance Sheet of the BoG, available at:

http://www.bankofgreece.gr/Pages/en/Statistics/monetary/nxi.aspx

\footnotetext{
${ }^{16}$ TARGET2 will be discussed in section 5 of this article. Suffice it to note that the debate was initiated by Hans-Werner Sinn who claimed that TARGET2 credits were a form of financing provided by the German Bundesbank to cover current account deficits and capital flight in peripheral Eurozone countries, see Sinn and Wollmershäuser (2012). See Whelan (2012), Buiter and Rahbari (2012) and Ceccheti, McCauley and McGuire (2012) for arguments against restricting the provision of TARGET2 credit by the Bundesbank. See also Tuori (2016) who rightly rejects the idea that TARGET2 is a mechanism for redistribution among EMU countries.
} 
*As of June 2015, 'capital \& reserves' includes current year results and valuation adjustments.

The asset side contains claims on MFIs and non-MFls (basically the Greek government) which could potentially be redenominated, on the assumption that claims of BoG on domestic MFls would be subject to Greek law. Note particularly the claims of nearly EUR 69bn on Greek banks largely comprising liquidity provision, of which more than EUR 40bn in 2016 was Emergency Liquidity Assistance (ELA). Note that ELA is provided through the Eurosystem but is the responsibility of each National Central Bank, in this case, the BoG. The surprising element on the asset side, however, are securities held to the value of EUR 53278mn which are non-domestic and would not be possible to redenominate. This part of the balance sheet of the BoG appears to be linked to monetary policy operations of the ECB and the Eurosystem, and has grown systematically since 2013 , as is shown in the next section.

On the liability side the BoG has issued EUR 30728mn of banknotes and coin, the legal responsibility for which belongs to the Eurosystem and would thus remain after the change of currency. Note further that about EUR 13bn of banknotes are also held by the Greek public, which are included in the EUR $18107 \mathrm{mn}$ of Remaining Liabilities. This is part of the extraordinary hoarding of banknotes in the course of the crisis which has resulted in a further allocation of banknote liability to the BoG within the Eurosystem beyond its normal allocation. ${ }^{17}$ The most significant liability of the BoG, however, is undoubtedly that owed to the Other Euro Area, coming to EUR 72257mn which includes the TARGET2 exposure of the Greek central bank. The legal status of that borrowing is far from clear and merits detailed discussion below.

On this basis, the Net Relevant Position of the BoG is shown in Table 14:

\footnotetext{
${ }^{17}$ See Lancaster (2011 and 2016).
} 
Table 14. Net Relevant Position of the Bank of Greece, December 2016, EUR mn

\begin{tabular}{|l|l|l|l|}
\hline \multicolumn{2}{|l|}{ ASSETS } & \multicolumn{2}{l|}{ LIABILITIES } \\
\hline $\begin{array}{l}\text { Securities, Other } \\
\text { Euro Area }\end{array}$ & $\begin{array}{l}\text { Liabilities to } \\
\text { MFIs, Other Euro } \\
\text { Area }\end{array}$ & 72257 \\
\hline $\begin{array}{l}\text { Securities, Other } \\
\text { Countries }\end{array}$ & 16494 & & \\
\hline Total & 53278 & Total & 72257 \\
\hline $\begin{array}{l}\text { Net Relevant Position, if TARGET2 } \\
\text { could not be redenominated }\end{array}$ & $\mathbf{- 1 8 9 7 9}$ & \\
\hline $\begin{array}{l}\text { Net Relevant Position, if TARGET2 } \\
\text { could be redenominated }\end{array}$ & $\mathbf{5 3 2 7 8}$ \\
\hline
\end{tabular}

In all, the position of the BoG appears surprisingly robust, first, due to the large volume of foreign bonds held and, second, because the legal status of TARGET2 liabilities is unclear and requires detailed consideration. They are both discussed in the remaining part of this paper.

\section{TARGET2 and the acquisition of foreign securities by the BoG}

Large scale acquisition of securities issued by Other Euro Area and Other Countries represents a remarkable change in the balance sheet of the BoG. Figure 1 below shows the sudden and rapid growth of these holdings since the end of 2013. The sharpest acceleration in acquisitions occurred in the summer of 2015 , at a time of intense political uncertainty marked by a referendum with regard to accepting the third bail-out conditions.

The policy of acquisitions appears to be related to the monetary policies of the ECB, above all, Quantitative Easing. The programme of Quantitative Easing 
started in early 2015 and amounted to massive purchases of government bonds by the Eurosystem. By early 2018 total holdings were in excess of EUR 2tr, the great bulk of which were held by the National Central Banks that comprise the Eurosystem, although the ECB also bought substantial amounts. The BoG has participated in the programme and thus expanded its stock of government bonds, as is shown in tables 13 and 14. Interestingly enough, that stock might act as protective buffer in case of redenomination. 
Fig. 1. Securities of Other Euro Area and Other Countries held by the BoG, EUR mn

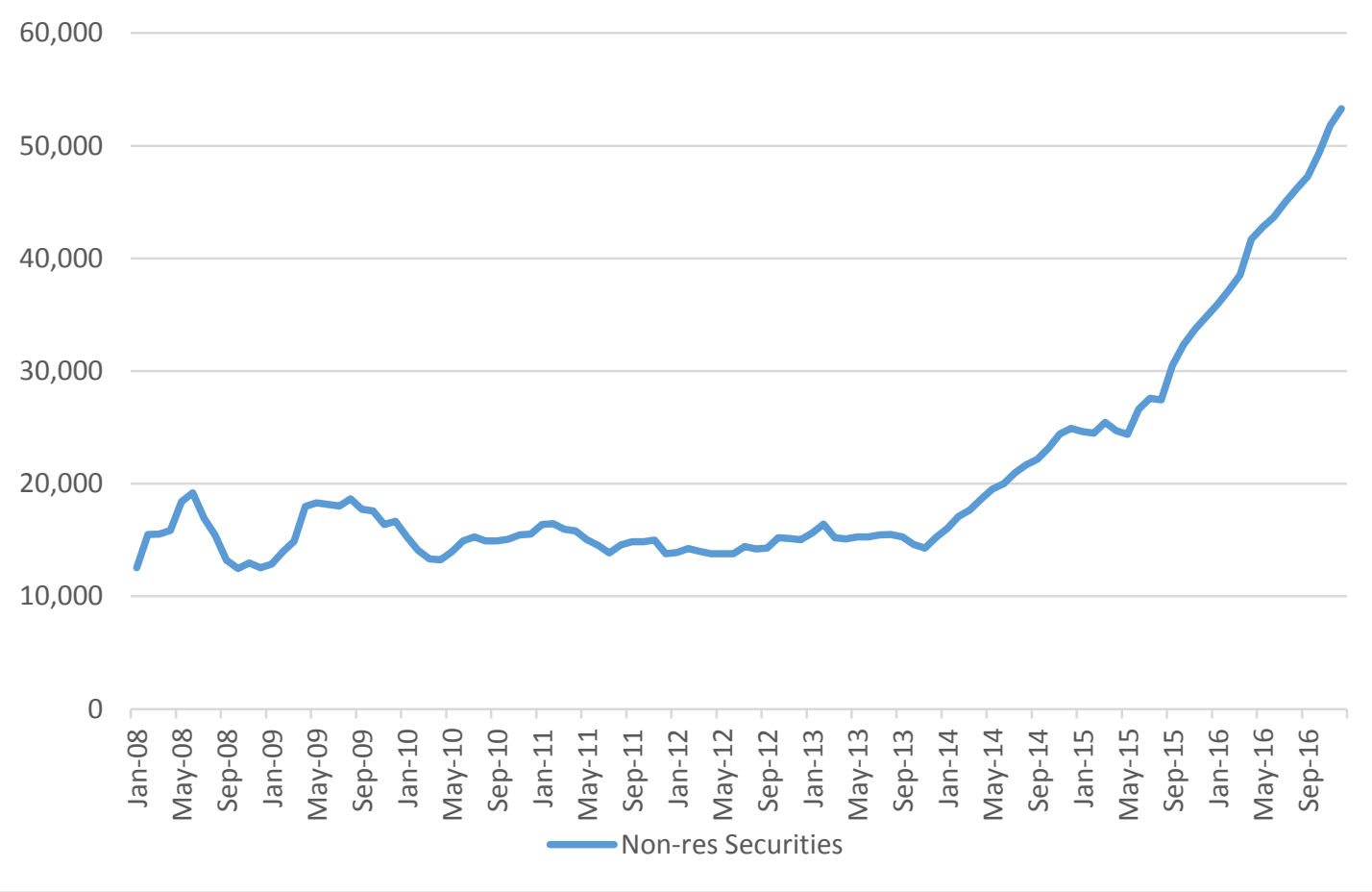

Source: Constructed from BoG, Balance Sheet of the BoG, available at:

http://www.bankofgreece.gr/Pages/en/Statistics/monetary/nxi.aspx 
Further insight into the position of the BoG and the potential role of its stock of foreign bonds could be gained by considering the borrowing of the BoG from the Eurosystem relative to its own lending to Greek banks in Figure 2:

Fig. 2. BoG Liabilities to Other Euro MFIs plus Remaining Liabilities compared to Claims to Domestic MFIs, EUR mn

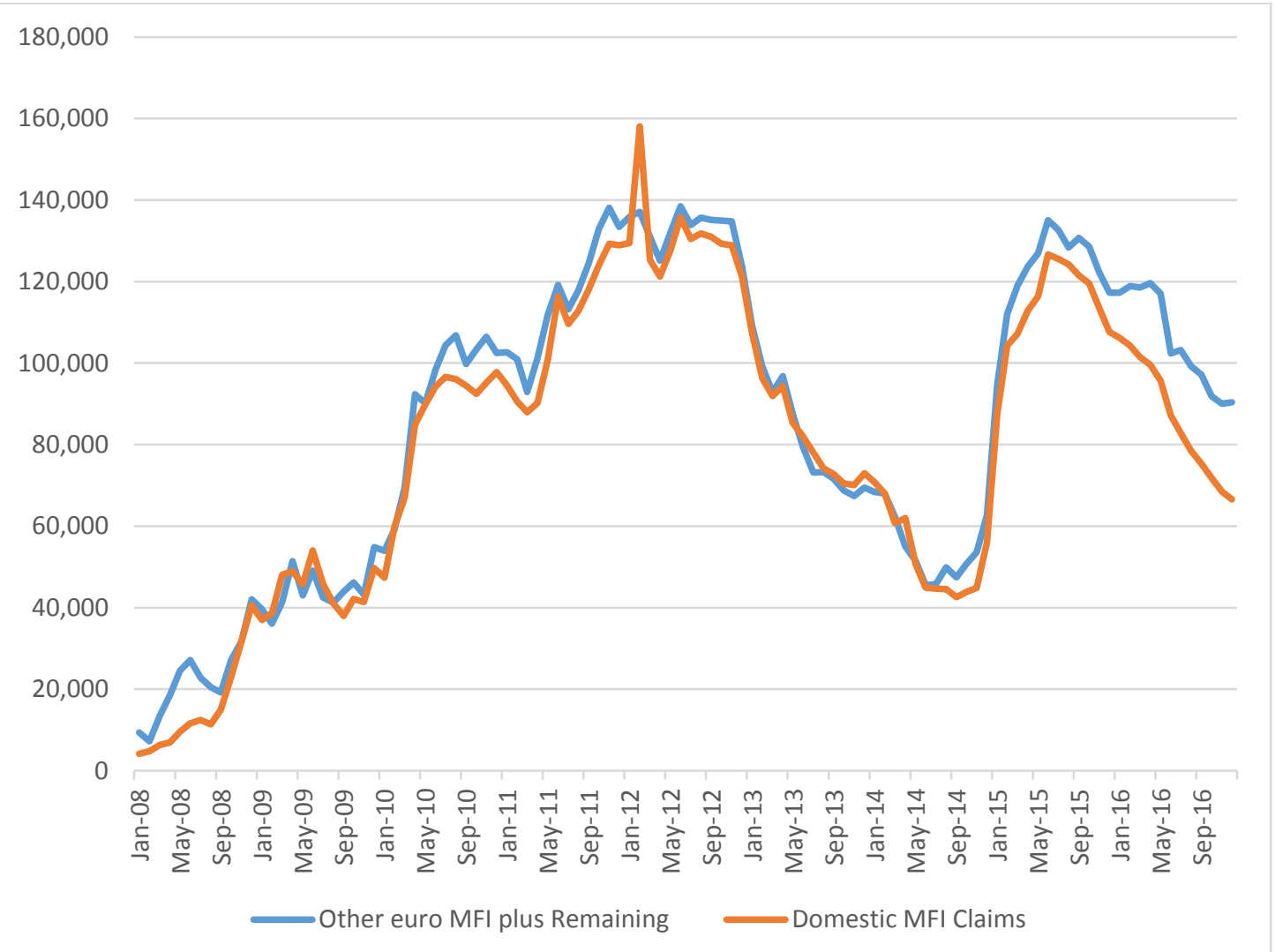

Source: Constructed from BoG, Balance Sheet of the BoG, available at:

http://www.bankofgreece.gr/Pages/en/Statistics/monetary/nxi.aspx 
Liquidity provision by the BoG appears in Figure 2 as Claims on Domestic MFIs. BoG liquidity was instrumental in allowing Greek banks to survive the crisis. In its absence there is no doubt that Greek banks would have shut their doors, effectively forcing a Greek exit from the EMU. Provision of BoG liquidity peaked in late 2011 and early 2012 as the Eurozone crisis reached its sharpest point for Greece. Provision also increased dramatically after the election of the radical SYRIZA government in 2015.

Liquidity provision by the BoG to Greek banks is almost perfectly matched by the borrowing of BoG from the Eurosystem, appearing as Liabilities to Other Euro Area MFIs. The latter comprises primarily TARGET2, plus the Remaining Liabilities of the BoG, which include in large part additional banknotes, as was already mentioned. The fit is remarkably close confirming that the BoG, and the Eurosystem behind it, acted as suppliers of liquidity of last resort to Greek banks in the course of the crisis. As capital flight from Greece ballooned and also as the Greek public began to hoard banknotes, Greek banks lost deposits. The loss of deposits was made up by liquidity supplied by the BoG, which acquired an equivalent liability toward the Eurosystem and other Euro area lenders.

The fit, however, became less perfect after the summer of 2015 as the liabilities of BoG to the Euro area began to exceed its provision of liquidity to Greek banks. That was also the time that the BoG began rapidly to accumulate foreign bonds. The gap observed between the two curves reflects the substantial foreign bond accumulation by the BoG. Some of the liabilities of the BOG, including TARGET2, correspond to a large volume of bonds that would not be redenominated in case of Greek exit from the EMU.

Essentially the same point also emerges from Fig. 3, which compares the foreign securities acquired by the BoG, shown in Fig. 1, relative to the sum of liabilities to other Euro MFIs plus Remaining Liabilities minus the claims by the 
BoG on domestics MFIs. The fit is manifestly close, indicating again that the BoG has been using some of its liabilities to the Euro area to increase its holdings of foreign securities.

Fig. 2 BoG Acquisition of Foreign Securities and Corresponding Liabilities

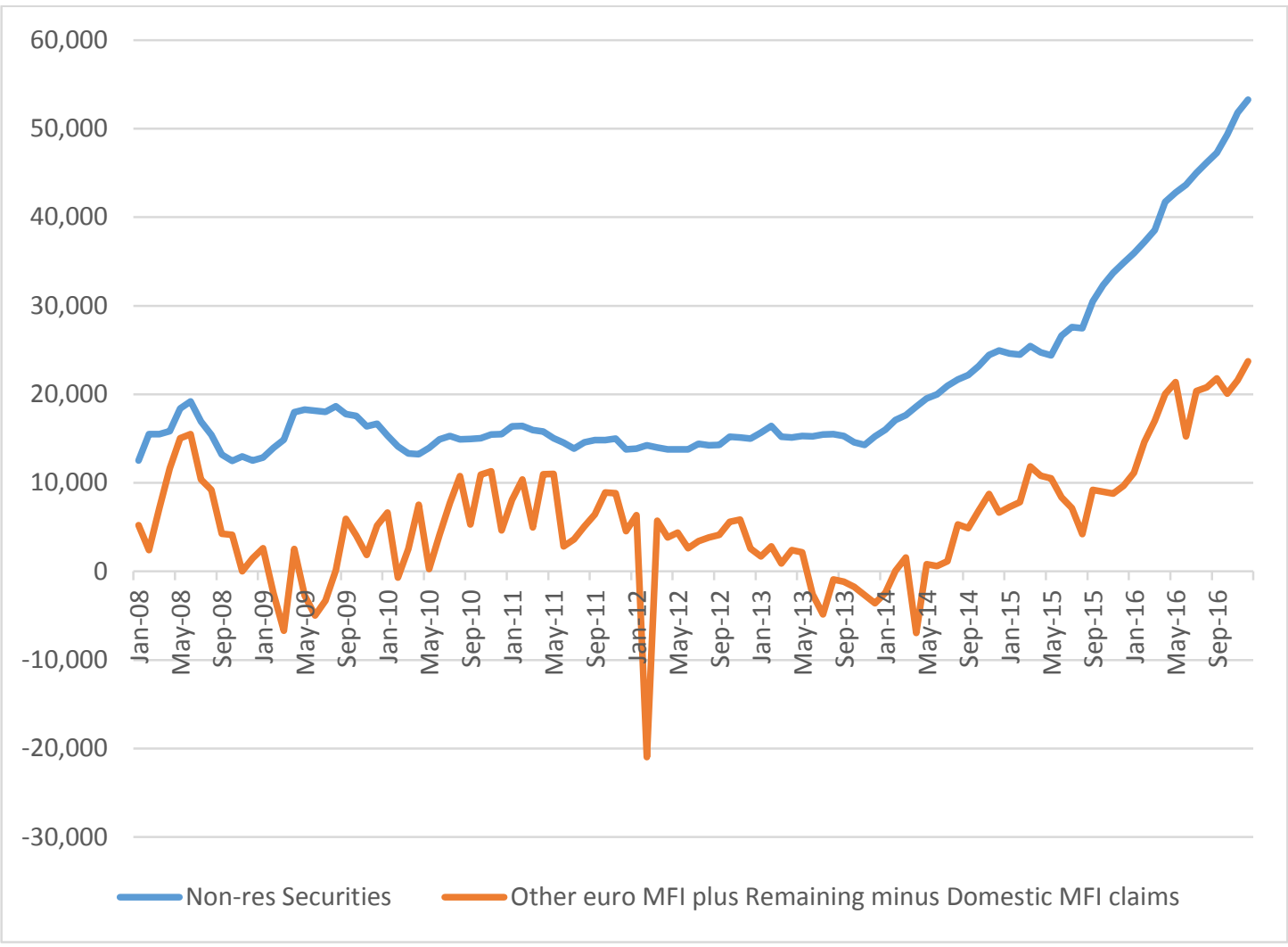

Source: Constructed from BoG, Balance Sheet of the BoG, available at:

http://www.bankofgreece.gr/Pages/en/Statistics/monetary/nxi.aspx

It is possible that this development is purely the result of the BoG participating in the Eurosystem and complying with Quantitative Easing. Even so, the outcome could substantially change the implications of redenomination for the BoG by improving its Net Relevant Position, since these holdings would remain primarily in euros. Further legal analysis of the status of these bonds in case of EMU exit is desirable. The deeper question remains, however, what would be the status of BoG TARGET2 borrowings in case of redenomination? 
There has been a lively academic and public debate on TARGET2 since the outbreak of the crisis as claims and liabilities within the system reached EUR 1tr in 2016-17. As Tuori (2016, pp. 843-47) notes, while the EMU continues to exist, TARGET2 assets and liabilities are merely clearing entries among central banks of little significance within the Eurosystem. However, if a country exited, the obligations of its National Central Bank would impose losses on the Eurosystem. Not surprisingly, the Governor of the ECB in a letter to two Members of the European Parliament formally declared that "If a country were to leave the Eurosystem, its national central bank's claims on or liabilities to the ECB would need to be settled in full." 18 There is, nonetheless, reason to doubt the validity of the Governor's claim.

TARGET2 is a payment system with over 1500 direct participants and 16000 indirect participants or correspondents. It is based on a single technical platform, but legally contains 19 separate component systems, one for each of the 18 National Central Banks of the Eurosystem, plus one for the ECB. The systems operated by the NCBs are governed by the relevant national legislation which implements the Settlement Finality Directive. Problems arising from legal differences among member-states have been addressed by creating a set of Harmonised Conditions. The Decision of the ECB that created TARGET2 states that: ${ }^{19}$

"1. The bilateral relationship between the E.C.B. and participants in TARGET2-E.C.B. shall be governed by the law of the Federal Republic of Germany.

2. Any dispute arising from a matter relating to the relationship referred to in paragraph 1 falls under the exclusive competence of the courts of

\footnotetext{
${ }^{18}$ Available at http://www.ecb.europa.eu/pub/pdf/other/170120letter valli zanni 1.en.pdf

${ }^{19}$ See Decision of the European Central Bank, 24 July 2007, creating TARGET2 (ECB/2007/7), available at https://www.ecb.europa.eu/ecb/legal/pdf// 23720070908en00710107.pdf
} 
Frankfurt am Main, without prejudice to the competence of the Court of Justice of the European Communities."

Thus, although TARGET2 operates on a single technical platform, it is legally structured as a multiplicity of systems. Each NCB owns its TARGET2 component and operates it under its national law. The TARGET2 components of individual central banks encompass the Payment Module and the Dedicated Cash Accounts on their books. The ECB also owns its own TARGET2 component and operates it under German law.

Each TARGET2 component is designated under the relevant national legislation implementing the Settlement Finality Directive (98/26/EC). However, the net positions of the Payment Modules operated by NCBs are settled at the ECB Payment Module accounts that NCBs hold with the ECB. The ECB holds assets for each net debtor liability of NCBs and vice-versa. Settlements of NCBs with the ECB constitute a bilateral relation between NCBs and the ECB, as part of TARGET2-ECB. This makes it quite clear that such relations would be governed by German Law. Should an NCB default on its obligations under TARGET2 to the ECB there would be a process of mobilising collateral subsequent to which the ECB would actually recognise a loss and write it off as a bad debt. The ECB could then call on its shareholders, i.e., the remaining NCBs of the Eurozone to participate in the loss according to their shares in the ECB's capital.

However, neither the German Banking Act, nor European or National laws mention the possibility of the Eurozone break-up, nor do they specify the procedure for redenominating claims and liabilities to the ECB. The texts refer solely to default. In case of a break-up and redenomination it might be possible to argue that default of a National Central Bank did not actually take place, and thus the provisions for dealing with disputes within the Eurosystem framework would not be pertinent. In that case the national Lex Monetae could be 
applicable to NCBs liabilities with the ECB. It is conceivable that, if the BoG stopped being part of the ECB and Greece changed its national legal tender, TARGET2 liabilities of the BoG would not be governed by German law, leaving open the option of redenomination.

\section{Conclusion}

The redenomination risk of Greek exit from the EMU is summed up in Table 14, which shows the Net Relevant Position of the four sectors examined in this paper:

Table 14 Net Relevant Positions in Greece, December 2016

\begin{tabular}{|l|l|l|}
\hline Sector & EUR $\mathbf{~ m n}$ & \% of real GDP * \\
\hline Public & -267311.92 & -144.8 \\
\hline Private (Non-Banking) & 38638 & 20.9 \\
\hline Banking & 32613 & 17.7 \\
\hline Bank of Greece & -18978, with TARGET2 & -10.3 \\
\hline Bank of Greece & 53278, without TARGET2 & 28.9 \\
\hline
\end{tabular}

${ }^{*}$ Estimated at EUR 184490mn, Hellenic Statistical Authority, available at:

http://www.statistics.gr/en/statistics/-/publication/SEL15/-

The results are broadly consistent with those of Durand and Villemot (2016). The bulk of the redenomination risk is concentrated in the Public Sector, and there is no doubt at all that in the event of exit Greece would have to declare default and seek deep restructuring of its public debt. The Net Relevant Positions of both the Private (Non-Financial) Sector and of the Banking Sector, however, are clearly positive and unlikely to change drastically in the near future. 
From the perspective of the private economy, therefore, the "balance sheet effect" of exit is likely to be positive, though the distribution of the effect across the Non-Financial and the Banking Sector is likely to be uneven, and hence some agents would be adversely affected. The distribution is not possible to assess, given the data available at present.

The more unpredictable and complex part of the redenomination risk refers to the BoG, and is a result of the support that the central bank has given to the Greek Banking Sector in the course of the crisis. The liabilities of the BoG, however, have a different legal and economic status compared to the debt of the Public Sector, leaving open the question of redenomination. In view especially of the accumulation of foreign securities by the BoG during the last several years, the position of the BoG is not as weak as it might appear at first sight.

In sum, the redenomination risk from Greek exit from the EMU is modest, provided that the country was prepared to confront the prospect of state default, which would be unavoidable. There is little reason to expect recessionary pressures to arise purely because of redenomination. The impact on exports and imports, on the other hand, would certainly be beneficial in the short to medium term.

Needless to say, Greek exit from the EMU would have profound political implications for the domestic structures of authority, especially in view of state default. It would also have equally profound international implications as Greece would be obliged to default on public debt held by official lenders. But the economic benefits to Greece in its current predicament are evident, and the economic risks are modest. Moreover, the process would be far less painful for all, if it were consensual. A key factor in this respect would be to support the Greek banking system and to ensure regular supply of basic goods. Perhaps the most critical element, however, would be to limit the depreciation of the new 
currency. The ECB is perfectly capable of ensuring this outcome, which would also reduce the potential losses for holders of Greek public debt. Unfortunately, such support is unlikely to be offered to Greece in the foreseeable future. Nonetheless, the issue of exit is almost certain to confront Greece and the EMU again in the future. It is useful to know that at that time redenomination risk is unlikely to be a major concern. 


\section{References}

Amiel, D. and P.A. Hyppolite, 2015, 'Is There an Easy Way Out? Private Marketable Debt and its Implications for a Euro Breakup: The Case of France', Cahier no. 2015-02, École Polytechnique.

Arestis, P. and M. Glickman, 2002, 'Financial Crisis in Southeast Asia: dispelling illusion the Minskyan way', Cambridge Journal of Economics, 26: 2, pp. 237-260.

Buiter, W. and E. Rahbari, 2012, 'TARGET2 redux: the simple accountancy and slightly more complex economics of Bundesbank loss exposure through the Eurosystem', CEPR, Discussion Paper, no 9211, November.

Ceccheti S., R. McCauley and P. McGuire, 2012, 'Interpreting TARGET2 balances'. BIS Working Papers, no 303.

Durand C. and S. Villemot, 2016, 'Balance Sheets After the EMU: An Assessment of the Redenomination Risk', OFCE, Sciences-Po, Working Paper 2016-31, October.

Flassbeck, H and C. Lapavitsas, 2015, Against the Troika: Crisis and Austerity in the Eurozone, with $\mathrm{H}$. Flassbeck, Verso: London and New York.

Gourinchas, P.O., T. Philippon, and D. Vayanos, 2016, The Analytics of the Greek Crisis, in M. Eichenbaum and J. Parker (eds), NBER Macroeconomics Annual 2016, Volume 3, available at http://www.nber.org/papers/w22370.pdf (last accessed 10.3.2018).

Katsinos, A. and T. Mariolis, 2012, Switch to devalued drachma and risk-push inflation: A simple input-output approach to the Greek case, Modern Economy, 3, pp. 164-170.

Krugman, P., 1999, 'Balance sheets, the transfer problem, and financial crises', in Isard P., Razin A., Rose A. (Eds.), International Finance and Financial Crises: Essays in Honor of Robert Flood, Kluwer Academic PublishersIMF.

Krugman, P., 2000, 'Crises: The price of globalization?', in Global Economic Integration : Opportunities and Challenges, Federal Reserve Bank of Kansas City, pp. 75-105, available at:

https://www.kansascityfed.org/publicat/sympos/2000/S00krug.pdf (last accessed 10.3.2018).

Lancaster, J., 2011, 'Eurosystem debts, Greece, and the role of banknotes', Lancaster University Management School, Monetary Research, available at:

http://www.lancaster.ac.uk/staff/whittaj1/eurosystemNov2011.pdf (last accessed 10.3.2018).

Lancaster, J. 2016, 'Eurosystem debts do matter', Lancaster University Management School, Monetary Research, available at: 

accessed 10.3.2018).

Lapavitsas, C., T. Mariolis, with K. Gavrielidis, 2017, "Eurozone failure, German policies, and a new path for Greece: Policy analysis and proposals", Rosa Luxemburg Stiftung Publikationen, available at

http://www.rosalux.de/fileadmin/rls uploads/pdfs/sonst publikationen/O nline-Pub Eurozone Failure.pdf (last accessed 7.3.2018).

Miliarakis P. 2015, 'The Legal Aspects of Greek Exit from the EMU', in Flassbeck and Lapavitsas (2015).

Miliarakis P. 2016. 'Legal Issues of the Transition to a National Currency in the European Union', Paper presented at the conference on "Eurozone, Popular Sovereignty and National Currency", 15-17 January, Athens University of Economics, http://www.maxome.gr/wp-

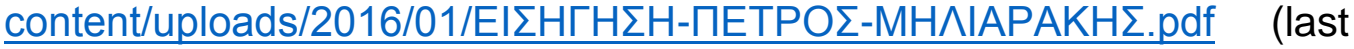
accessed 7.3.2018).

Minenna, M., A. Guglielmi, J. Suárez, C. Signani, 2017, 'Italy: Re-denomination risk down as time goes by', Mediobance Securities country Update, 17 January.

Nikiforos, M., D. Papadimitriou, and G. Zezza, 2016, "The Greek Public Debt Problem", Working Paper No. 867, Levy Economics Institute of Bard College, May, available at: http://www.levyinstitute.org/pubs/wp 867.pdf (last accessed 10.3.2018)

Nordvig, J., 2014, 'Risks and Benefits of Eurozone Breakup: The role of contract redenomination and balance sheet effects in policy analysis' available at:

http://jensnordvig.com/wpcontent/uploads/2016/01/RiskBenefitsBreakup.pdf (last accessed 10.3.2018).

Nordvig, J. and N. Firoozye, 2012, 'Rethinking the European monetary union', Wolfson Economics Prize, Final Submission, available at: https://ftalphaville-cdn.ft.com/wp-content/uploads/2012/07/Rethinkingthe-European-Monetary-Union-Adapt.pdf (last accessed 10.3.2018)

Petch T. and K. Meloni, 2012, Legal Aspects of the Eurozone Crisis, Slaughter and May, London.

Proctor, C., 2010, 'The euro-fragmentation and the financial markets', Capital Markets Law Journal, 6:1, pp. 5-28.

Sinn, H.W. and T. Wollmerhäuser, 2012, 'TARGET loans, current account balances and capital flows: The ECB's rescue facility', International Tax and Public Finance, vol. 19, no. 4, pp. 468-508.

Tuori, K. 2016, "Has Euro Area Monetary Policy Become Redistribution by Monetary Means? 'Unconventional' Monetary Policy as a Hidden Transfer Mechanism', European Law Journal, 22(6): 838-868.

Whelan. K., 2012, 'TARGET2: Not why Germans should fear a euro breakup', VoxEU, 29, April. 